\title{
Novel strategies in tendon and ligament tissue engineering: Advanced biomaterials and regeneration motifs
}

\author{
Catherine K Kuo ${ }^{1}$, Joseph E Marturano ${ }^{1}$, Rocky S Tuan ${ }^{2 *}$
}

\begin{abstract}
Tendon and ligaments have poor healing capacity and when injured often require surgical intervention. Tissue replacement via autografts and allografts are non-ideal strategies that can lead to future problems. As an alternative, scaffold-based tissue engineering strategies are being pursued. In this review, we describe design considerations and major recent advancements of scaffolds for tendon/ligament engineering. Specifically, we outline native tendon/ligament characteristics critical for design parameters and outcome measures, and introduce synthetic and naturally-derived biomaterials used in tendon/ligament scaffolds. We will describe applications of these biomaterials in advanced tendon/ligament engineering strategies including the utility of scaffold functionalization, cyclic strain, growth factors, and interface considerations. The goal of this review is to compile and interpret the important findings of recent tendon/ligament engineering research in an effort towards the advancement of regenerative strategies.
\end{abstract}

\section{Review}

The primary role of tendon and ligament is to transfer forces between musculoskeletal tissues. Adult tendon and ligament have relatively low oxygen and nutrient requirements, low cell density, and poor regenerative capacity, yet they experience some of the highest mechanical loads in the body. When these loads exceed a critical threshold that causes permanent tissue damage, impaired function and mobility will result. For the repair of both tissues, given their very low selfregenerative capacity, typically the only recourse is surgical intervention. Current surgical reparative techniques rely on tissue replacement with auto- or allografts, and are often accompanied with additional problems such as donor site morbidity, pain and graft failure. A more ideal solution would be to fully restore the tendon or ligament tissue to its pre-injured state. This is the promise of tissue engineering, a field which aims to incorporate specific cell types into a biodegradable scaffold which when implanted will gradually regenerate into a

\footnotetext{
* Correspondence: rst13@pitt.edu

${ }^{2}$ Center for Cellular and Molecular Engineering, Department of Orthopaedic Surgery, University of Pittsburgh School of Medicine, Pittsburgh, PA 15219, USA

Full list of author information is available at the end of the article
}

tissue that closely resembles the original tissue and restores functionality. In this review, we outline the state of the art of tendon and ligament $(\mathrm{T} / \mathrm{L})$ tissue engineering. Relatively little is known about these tissues as compared to other musculoskeletal tissues such as bone, cartilage and muscle, though recent studies have made significant advances, and distinct biological differences between tendon and ligament are beginning to be recognized [1-3]. However, from an engineering standpoint these tissues are functionally similar, and thus as reviewed here, tissue engineering efforts commonly refer to these tissues interchangeably. This review will discuss biomaterial selection and functionalization, scaffold design, cellular activities critical for tissue function, and recent outcomes of long-term implantation studies in animal models.

Native tendon and ligament macromolecular composition and microenvironment

$\mathrm{T} / \mathrm{L}$ properties that tissue engineers often try to mimic are the biochemical composition and structure, cell population, and mechanical properties of a native tissue. $\mathrm{T} / \mathrm{L}$ obtain their tensile strength and elasticity from the molecular building block of their structure: triple-helical type I collagen molecules. A dimensional hierarchy 
exists where collagen molecules ( $1 \mathrm{~nm}$ diameter) organize into parallel nanoscale fibrils, and subsequently into microscale fibers, both highly aligned along the major axis of the T/L unit. Fibril diameters range from 50$100 \mathrm{~nm}$ during embryonic development [4] and can reach as large as $280 \mathrm{~nm}$ in adults [5], and show a characteristic $67 \mathrm{~nm}$ lateral D-banding pattern coincident with molecular gaps [6]. Collagen type I fibrils account for the majority $(\sim 60 \%)$ of $\mathrm{T} / \mathrm{L}$ dry mass and are surrounded by other proteins, including collagen types III, IV, V, and VI, and small-leucine rich proteins (SLRPs), such as decorin and cartilage oligomeric matrix protein (COMP), amongst others $[7,8]$. The functions of these matrix proteins are to permit gliding of fibril bundles and viscoelastic responses to load, provide secondary crosslinking, assist with collagen fibril organization, and provide space for proprioceptive neural networks and vascular supply. One of the largest molecular differences between tendons and ligaments is their elastin content; human tendon is $2 \%$ elastin (dry wt.) [1], but in ligament can range between $5 \%, 7.3 \%$ or $47 \%$ (dry wt.) in the human anterior cruciate ligament [9], posterior longitudinal ligament [2] and ligamentum flavum [10], respectively. Another difference is that tendon may have up to $34 \%$ higher pyridinoline content, a mature collagen crosslinker, compared to ligament (normalized to collagen content) [3].

$\mathrm{T} / \mathrm{L}$ cells are circumferentially oriented around collagen fibers and are responsible for maintaining the density and composition of the T/L matrix. By convention, fibroblastic cells in tendon are known as "tenocytes", whereas in ligament they are known as "ligament fibroblasts". T/L cells communicate with each other using extended cell processes that terminate in connexin 32 and 43-positive gap junctions [11], and have a small multipotent stem cell population [12]. In areas of high compressive force, such as in wrap-around tendons or near a bone insertion (enthesis), fibrocartilage cells are also present [13]. Although gene-based identification of $\mathrm{T} / \mathrm{L}$ cells is currently incomplete, promising markers of $\mathrm{T} / \mathrm{L}$ cells include the transcription factor scleraxis $(\mathrm{Scx})$ [14], the transmembrane protein tenomodulin (Tnmd) [15], and the extracellular matrix (ECM) glycoprotein tenascin-C (TN-C) [16]. Unfortunately, these cell populations show very poor healing efficacy in vivo; animal models have demonstrated that the mechanical properties of injured T/L are not recovered even after 12 months of healing [17].

The mechanical properties of $\mathrm{T} / \mathrm{L}$ are highly complex and unique owing to their hierarchical structures and complex protein compositions. The normal response to load is non-linear, anisotropic, and viscoelastic, showing over $50 \%$ stress relaxation in $120 \mathrm{~min}$ [18]. Elastic moduli of adult human Achilles tendon measured in vitro have been found to be between 0.8-1.5 GPa [19], which is comparable and slightly higher than in vivo ultrasound and reaction force-plate measurements at $0.87 \pm$ $0.2 \mathrm{GPa}$ [20] or $1.16 \pm 0.15 \mathrm{GPa}$ [21]. In vivo peak bulk tissue strains in these studies have been estimated to be $8.3 \pm 2.1 \%$ [20] with $18 \%$ hysteresis [21]. These properties are not comparable to cadaver Achilles or patellar tendon, which typically have elastic moduli between 200-270 MPa [22]. Although no material can accurately match the stiffness, ductility, non-linearity, and viscoelastic response of native tendon, one of the major goals of $\mathrm{T} / \mathrm{L}$ engineering is to combine the appropriate biodegradable scaffold with cells and cellular cues to induce ECM remodelling that closely matches the mechanical properties and biochemistry of native tendon. Researchers have investigated both natural and synthetic biomaterials, in conjunction with many cell types, for this purpose.

\section{Synthetic biomaterials in tendon and ligament tissue engineering}

An ideal engineered $\mathrm{T} / \mathrm{L}$ would contain enough starting biomaterial for immediate load bearing post-implantation, and would degrade at a rate comparable with that of developing cellular and tissue in-growth. After a period of several weeks or months the starting material, or scaffold, would be completely replaced by regenerating $\mathrm{T} / \mathrm{L}$ cells and matrix. The requirement for biodegradability and fabrication into specific tendon- and ligament-like geometries has generated interest in the use of synthetic polymer materials for $\mathrm{T} / \mathrm{L}$ tissue engineering [23].

Polyhydroxyesters degrade by hydrolysis and thus have been very popular for T/L tissue engineering. An early cell attachment study found that anterior cruiciate ligament (ACL)-derived fibroblasts adhered and proliferated on poly ( $\varepsilon$-caprolactone) (PCL), $\mathrm{PCL} /$ poly(DL-lactide) (PLA) (50:50), and poly(DL-lactide-co-glycolide) (PLGA) (50:50) two-dimensional substrates at a rate that was not significantly less than tissue-culture plastic [24]. Composites of these materials are often fabricated to tailor degradation rates and optimize surface energies since high hydrophilicity is thought to be detrimental to cell adhesion [25]. Several studies have built upon these earlier findings and extended $\mathrm{T} / \mathrm{L}$ cell culture into three dimensions (3D) with polyhydroxyester scaffolds.

$\mathrm{Lu}$ et al. [26] fabricated 3D braided scaffolds of PGA, PLGA, and poly(L-lactic acid) (PLLA) filaments at two levels of bundling using a circular braiding loom designed to mimic the hierarchical structure of native ligament. Scaffolds were immersed in a solution of human recombinant fibronectin (Fn) to improve cell adhesion. After 14 days of culture with rabbit ACL fibroblasts, scanning electron microscopy (SEM) analysis found that cells seeded on PLLA-Fn and PLGA-Fn 
scaffolds produced the most matrix, and that PGA was detrimental to matrix formation, thought to be from rapidly produced acidic byproducts (Fig. 1).

Interestingly, PGA-Fn had significantly reduced cell numbers compared to PLGA-Fn and PLLA-Fn scaffolds $(\mathrm{p}<0.05)$, the latter two being not significantly different from each other $(\mathrm{p}>0.05)$ [26]. The authors concluded that while both the PLLA-Fn and PLGA-Fn scaffolds would be effective for ligament tissue engineering, that the PLLA-Fn scaffolds may be the more appropriate choice due to their slower degradation rate. A study of the tensile properties of braided PLGA 10:90 scaffolds found ultimate tensile strengths between 100-400 MPa, and with a circular braiding scheme, a maximum load of over $900 \mathrm{~N}$, both of which were considered practical and safe for initial implantation in a human ACL replacement surgery [27]. Recent work has also elucidated ideal braiding angles of these scaffolds $\left(60-72^{\circ}\right)$ to more accurately mimic the non-linear stress-strain relationship of native T/L [28]. Taken together, these studies show great promise for future use of braided PLGA scaffolds for T/L replacement, particularly if the degradation profiles are optimally balanced against tissue ingrowth using an animal model.

Synthetic PLGA 10:90 scaffolds have also been co-fabricated with biopolymers such as collagen type I to form porous, rolled microsponges, to combine mechanical strength and cellular binding affinity for $\mathrm{T} / \mathrm{L}$ tissue engineering [29]. To fabricate the microsponges, PLGA was immersed in a solution of bovine collagen type I, freezedried and crosslinked with glutaraldehyde. Canine ACL fibroblasts were cultured on the scaffolds for 16 days in vitro before rolling and subcutaneous implantation in nude mice. Using hematoxylin and eosin (H\&E) staining, coupled with SEM analysis, the authors found that cells were viable and produced a uniform matrix in the scaffold center even after 12 weeks of implantation. This was a very encouraging result since the scaffolds had millimeter-scale diameters, much greater than the oftcited $\mathrm{O}_{2}$ diffusion limit of 200-300 $\mu \mathrm{m}$.

One of the advantages of synthetic polymers is that they can be processed relatively easily into fibers with nanometer-scale diameters - on the order of native collagen fibrils - using electrospinning [30]. Lee et al. [31] produced aligned polyurethane (PU) nanofiber scaffolds with average fiber diameter of $650 \mathrm{~nm}$ and $82 \%$ porosity using an electrospinning apparatus and a rotating collector target. Seeded human ligament cells were cultured for 48 hours then subjected to $5 \%$ uniaxial strain at $0.083 \mathrm{~Hz}$ using vacuum flexion on a silicone membrane for an additional 24 hours. Aligned scaffolds produced significantly more collagen mass (per DNA mass) compared to randomly oriented scaffolds $(\mathrm{p}<0.05)$, and aligned scaffolds showed cell morphologies that better resembled in vivo morphology. This study was one of several demonstrating the superiority of aligned, as opposed to random, nanofiber orientations for $\mathrm{T} / \mathrm{L}$ tissue engineering. Composite nano- and micro-fiber scaffolds have also been fabricated for $\mathrm{T} / \mathrm{L}$ tissue engineering [32]. In this study electrospun PLGA (65:35) nanofibers (300-900 nm dia.) were deposited onto a mesh of $25 \mu \mathrm{m}$ diameter PLGA (10:90) microfibers resulting in $\sim 2-50 \mu \mathrm{m}$ pores. The rationale for this system was that the microfibers would provide mechanical
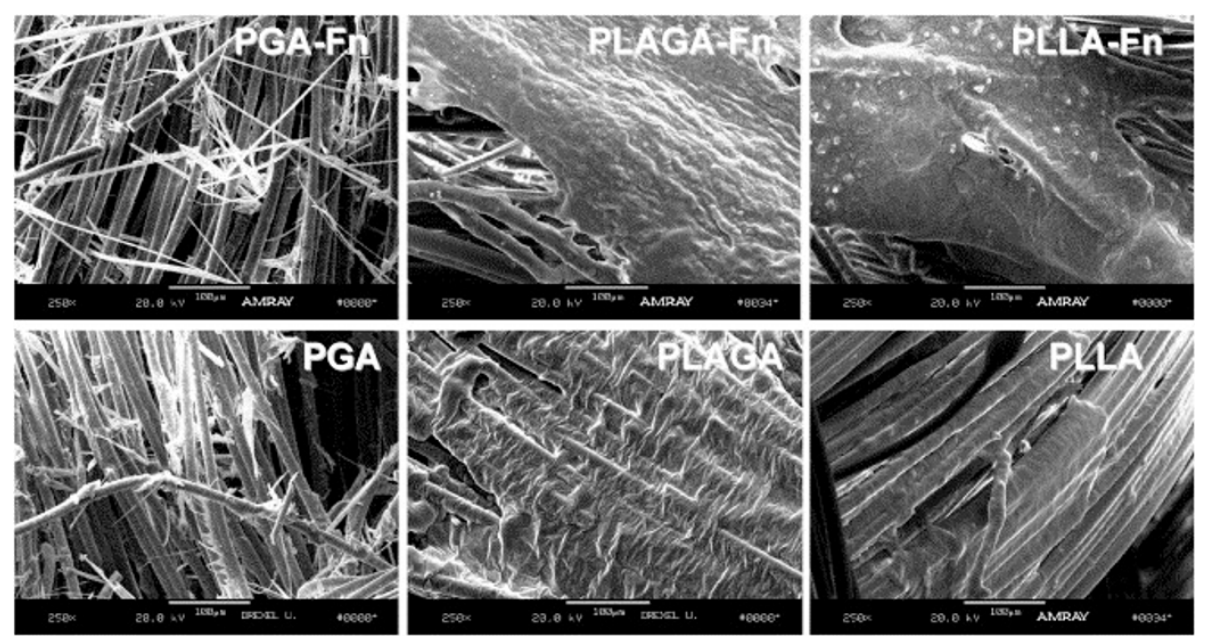

Figure $1 \mathrm{ACL}$ fibroblast growth and matrix formation on different synthetic braided scaffolds visualized with SEM [26]. Images were taken after 14 days of in vitro culture in 10\% fetal bovine serum. (Left) Culture with PGA resulted in substantial matrix degradation from acidic byproducts. (Middle) PLA and PGA in a 82:18 mass ratio showed more sustainable matrix formation, particularly with the addition of fibronectin (Fn). (Right) PLLA scaffolds also displayed considerable matrix formation, which again was amplified by the addition of Fn. Reproduced with permission from Elsevier B.V. 
strength and degradation resistance, and the nanofibers would provide hydrophilicity and a very high surface area for cell attachment. The authors seeded porcine bone-marrow derived mesenchymal stem cells (BMSCs) and measured an average collagen production of 1.55 ng/cell after 7 days which was considered a high level of matrix production relative to other scaffold geometries. Furthermore, mRNA expression levels of relevant $\mathrm{T} / \mathrm{L}$ genes, such as collagen type I, decorin, and biglycan (relative to the GAPDH), were all slightly upregulated (5-20\%), suggesting partial differentiation into $\mathrm{T} / \mathrm{L}$ lineages. A follow-up study reports further optimization of these scaffolds including enhanced cell attachment and proliferation using PCL and collagen type I surface deposition, and also a $\sim 50 \%$ increased failure load by incorporating a right-angle fiber weaving method [33].

These studies and others [34,35] demonstrate some of the advantages imparted by synthetic nanofiber technologies for $\mathrm{T} / \mathrm{L}$ tissue engineering, which will continue to expand and evolve as more specific T/L cell-nanofiber interactions are elucidated. At present, it appears that most studies show results favoring aligned nanofibers over randomly oriented fibers, likely due to their resemblance to native $\mathrm{T} / \mathrm{L}$ fibril orientation, but the ideal fiber materials, diameters, spacing, and angles remain unresolved for $\mathrm{T} / \mathrm{L}$ tissue engineering. Although single materials are often used, one promising strategy may to be incorporate fibers of different diameters and mechanical properties into a single aligned scaffold in an effort to mimic the multi-protein matrix of $\mathrm{T} / \mathrm{L}$, e.g. collagen type I, collagen type III, elastin, and proteoglycans. The rapid degradation rate of synthetic nanofibers must also be controlled and perhaps decelerated before in vivo implantation will be feasible. Overall, however, current synthetic nanofiber scaffolds are cytocompatible and have tailorable diameters and degrees of alignment, and are one of the most exciting prospects for the design of engineered $\mathrm{T} / \mathrm{L}$ tissues.

\section{Natural polymeric biomaterials in tendon and ligament tissue engineering}

We have seen that synthetic polymeric biomaterials have reproducible mechanical and chemical properties, are easily fabricated into different shapes and sizes, can degrade by hydrolysis, and are efficacious for T/L engineering research. However, they may lack functional chemical groups for cellular binding, and furthermore they may release acidic byproducts or unnatural polyesters into the bloodstream during degradation. For these reasons there has been considerable interest in the application of natural, protein-based fiber materials as scaffolds for $\mathrm{T} / \mathrm{L}$ tissue engineering [36-40]. The most direct and obvious choice for this material is collagen type I because of its prevalence in $\mathrm{T} / \mathrm{L}$ tissues.
Unfortunately, no method yet exists to organize and crosslink collagen fibers in a cytocompatible manner, and as such collagen gels remain exceptionally weak with typical elastic moduli between $10-30 \mathrm{kPa}$ and ultimate tensile strengths between $5-10 \mathrm{kPa}$ [41]. Thus collagen-based scaffolds, while useful to investigate mechanisms of tendon differentiation and regeneration [42] and the effects of mechanical stimulation [43,44], at present are limited for $\mathrm{T} / \mathrm{L}$ replacement.

Silk fibroin, rather than collagen, is a popular natural polymeric biomaterial used for $\mathrm{T} / \mathrm{L}$ tissue engineering. Silk fibroin is one of two proteins excreted by Bombyx mori silkworms during cocoon production and is typically isolated from its sister protein sericin using sodium carbonate, urea, and/or detergents, and near-boiling temperatures [45]. B. mori silk fibroin is $70-80 \%$ by mass of the silk bicomplex [46], contains a heavy (350 kDa) and light chain unit $(25 \mathrm{kDa})$, and is held together by the sticky cytotoxic sericin protein. The principal advantage of silk is its remarkable tensile strength and toughness (area under stress-strain curve) which is unmatched for natural proteins. Reported tensile mechanical properties of $B$. Mori silk fibroin range between 5-9 GPa for elastic modulus, 250-400 MPa for tensile strength, and 23-26\% for failure strain [47]. The protein also displays surface amino acids for cell adhesion, remains structurally whole in aqueous solutions but slowly degrades (weeks-months) proteolytically in vivo [48,49], and can be fabricated into gels, films, braided fibers or nanofibers. These characteristics make silk fibroin one of the best natural polymers for support of cellular and tissue ingrowth for $\mathrm{T} / \mathrm{L}$ tissue engineering.

Altman et al. were the first to design and test a braided silk fibroin scaffold seeded with bMSCs for $\mathrm{T} / \mathrm{L}$ engineering [50]. A braided geometry with four levels of bundles twisted with $0.5 \mathrm{~cm}$ pitch was chosen to effectively reduce the stiffness of a single fiber to better mimic native ACL mechanical properties. A fatigue analysis with a $400 \mathrm{~N}$ cyclic load indicated a matrix life (after linear extrapolation) of 3.3 million cycles, expected to far outlast in vivo degradation. After 14 days of in vitro culture with human bMSCs, the authors found that cell number increased 5-fold, and that considerable matrix had been deposited. Furthermore, mRNA analysis demonstrated expression levels of $\mathrm{T} / \mathrm{L}$ genes that were comparable to those in native human ACLs, such as an average collagen type I to type III ratio of $\sim 9$, an absence of collagen type II and bone sialoprotein (which would indicate cartilage or bone differentiation, respectively), and baseline expression of the $\mathrm{T} / \mathrm{L}$ marker tenascin- $\mathrm{C}$. The success of this initial work was considerable and highlighted the potential applicability of silk fibroin that has been properly processed and organized for in vivo $\mathrm{T} / \mathrm{L}$ replacement. 
Scaffold geometries other than braided structures have also been fabricated with silk fibroin. Liu et al. [51] surmised from previous studies of synthetic braided ligaments that such braided structures may have limited nutrient diffusion and tissue infiltration, particularly towards the center of the radial axis. To circumvent this potential issue, the authors fabricated a silk fibroin hybrid scaffold with geometries at two levels: a knitted scaffold and an interspersed microporous silk sponge. The knitted scaffold was fabricated using a 40-needle knitting machine, and the sponge was added by immersing the knitted scaffold in a low concentration silk solution, freeze drying to form pores, and then immersing in a methanol solution to prevent resolubilization. Compared with knitted scaffolds alone after 14 days of hMSC culture, the knitted-sponge scaffolds showed significantly higher biological responses with nearly every evaluation method ( $\mathrm{p}<0.05$ ), including cellular proliferation, GAG production, viable cell density, mRNA expression of collagen types I and III, and tenascin-C, and collagen-based matrix production, confirming the positive benefit of the microporous silk sponge. However, no significant differences in maximum tensile load or stiffness were recorded compared to unseeded scaffolds after 14 days, suggesting that the secreted matrix did not contribute towards scaffold strength. Also, the tensile strength and stiffness were far below $(<20 \%)$ those of the adult human ACL [52], which was their target tissue. Nevertheless, the cytocompatability and rapid T/L-like matrix development is impressive and further demonstrates the effectiveness of a cyto-friendly composite structure.

In addition to composite synthetic scaffolds, composite natural scaffolds have also been fabricated for T/L tissue engineering applications [53]. In this work a knitted silk fibroin base matrix was infiltrated with a freeze-dried collagen type I microsponge. MSC-seeded scaffolds were implanted into a rabbit medial cruciate ligament (MCL) transection model to evaluate in vivo repair potential over 12 weeks. In vitro, the authors found that gene expression levels of $\mathrm{T} / \mathrm{L}$-associated genes by cells seeded in silk-collagen scaffolds compared to silk alone were substantially higher, and showed collagen type I elevated by $250 \%$ and decorin elevated by over $500 \%$. Furthermore, histological analysis with H\&E and Masson's trichrome staining of the repairing MCL found more tissue ingrowth compared to silk alone and untreated MCLs after 2, 4, and 12 weeks (Fig. 2). These results suggest that a chimeric silk-collagen sponge matrix may be an effective treatment for MCL transections due to its rapid tissue ingrowth and favorable genetic expression results. Optimization of sponge pore size may be an important advancement in the development of these engineered T/L scaffolds.
One of the most important evaluation tests in $\mathrm{T} / \mathrm{L}$ engineering is the success of an engineered graft to be regenerated by the body into functional $\mathrm{T} / \mathrm{L}$. Recent long-term studies by Fan et al. have investigated silk scaffold T/L regeneration in rabbit [54] and pig models [55], providing new insights into the kinetics of $\mathrm{T} / \mathrm{L}$ tissue ingrowth and scaffold degradation. First, a rabbit ACL reconstruction model [54] was tested by transecting healthy rabbit ACLs and surgically implanting an MSC-seeded knitted silk scaffold with microporous silk sponge into bone tunnels of rabbit knees. A morphological and histological evaluation of implanted silk grafts replacing the rabbit ACL after 8 weeks suggested substantial production of collagen type I, collagen type III, and tenascin- $\mathrm{C}$, and that the ligament-bone attachment was stable (evaluated with micro-CT). However, similar to other studies with knitted silk scaffolds the tensile strength and stiffness were unfortunately well below those of native human ACL. A subsequent study using the larger porcine model showed similar, encouraging results. To compensate for the additional load bearing, the knitted-sponge silk scaffold was rolled around a braided silk cord and again seeded with MSCs. After 24 weeks the gross morphological and histological characteristics were evaluated and as before, collagen type I, collagen type III, and tenascin-C were all distinctly present as shown by immunohistochemistry analysis. However, with an average failure load of $398 \mathrm{~N}$, the authors noted that regenerated scaffolds at 24 weeks could be effective for mild daily load bearing, but would likely not survive trauma or vigorous exercise. Unfortunately the scaffold strength at earlier time points was not measured; it is clear however that 24 weeks would likely be too long for most patients to wait before mild load bearing would be feasible. Nevertheless the clinical implications of this study are profound, and demonstrate the in vivo effectiveness of a multi-structural silk scaffold for $\mathrm{T} / \mathrm{L}$ tissue engineering.

Because of their inherent biocompatibility, natural polymeric macromolecules will remain at the forefront of biomaterials research for $\mathrm{T} / \mathrm{L}$ tissue engineering. Although collagen type I gels may eventually be the scaffold material to use, their ultimate tensile strengths and elastic moduli are currently too low to act as a load bearing material. In the interim, silk fibroin has emerged as an excellent natural biomaterial alternative to collagen and has already been shown to regenerate $\mathrm{T} / \mathrm{L}$ in large scale animal models. Assuming the success of longer-term animal trials, it is anticipated that impending clinical trials with silk fibroin-based engineered ligaments will confirm the efficacy of silk to restore $\mathrm{T} / \mathrm{L}$ function after injury and offer an exciting new option for $\mathrm{T} / \mathrm{L}$ repair. 


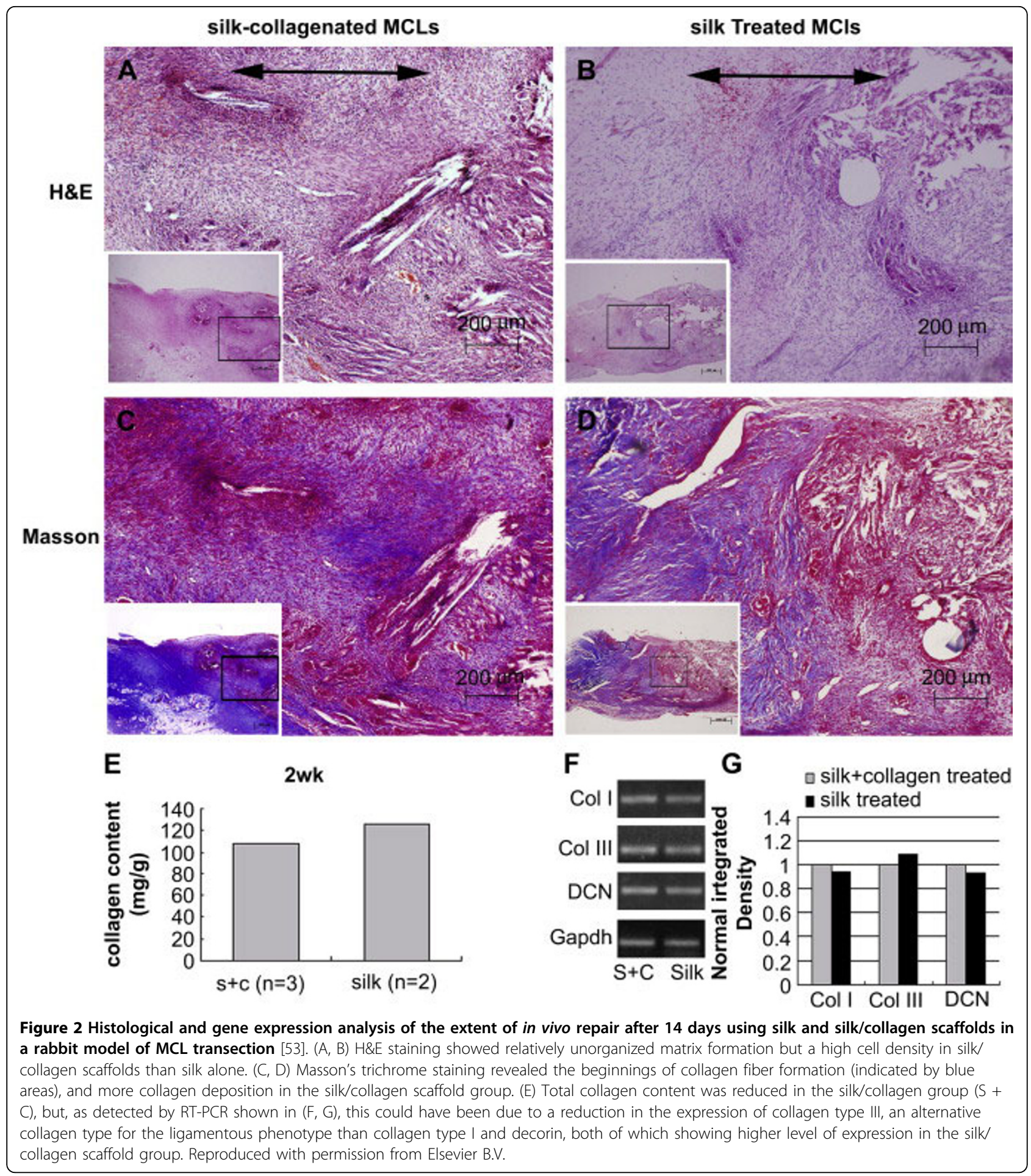

\section{Advanced scaffolds and signaling factors in ligament} tissue engineering

\section{A. Functionalized $T / L$ scaffolds}

One of the key factors in effective application of material scaffolds in tissue engineering is the optimization of cell-biomaterial interactions, particularly in terms of the ability of cells to adhere, proliferate, and secrete matrix onto the scaffold. Synthetic and natural polymers are effectively long chains of repeating chemical units, and it is thus possible to link small molecules covalently to their surfaces to enhance cell adhesion, proliferation, and matrix production. Such an approach has high 
potential, since biomaterials that natively lack chemical cell attachment groups can also be functionalized, thus expanding the range of implantable biomaterials. Cellmatrix interactions are typically mediated via cell surface integrin receptors, which are specialized transmembrane proteins that are connected cytoplasmically to the actin cytoskeleton. The most common example of an integrin-interacting matrix epitope is the peptide sequence, RGD (arginine-glycine-aspartic acid) [56], which has been used to functionalize a number of biomaterials.

The practice of functionalizing grafts to improve engineered tissues is sometimes done passively by merging one scaffold with another, for the purpose of combining mechanical properties with integrin binding capability. An example of passive functionalization is a recent work by Garcia-Fuentes et al. [57] who blended hyaluronan, a common native glycosaminoglycan, with silk fibroin and seeded MSCs for general regenerative applications. Matsumura et al. [58] conducted a more direct functionalization study and modified poly(ethylene-co-vinyl alcohol) (PEVA) films with carboxyl groups $(\mathrm{COOH})$ and subsequently covalently attached collagen type I, designed to enhance periodontal ligament adhesion to PEVA-coated titanium dental implants. Other general tissue engineering applications have used a variety of functionalizing groups including phosphate, amide and sulfonate groups.

There has been some interest in adding functional groups to non-degradable synthetic graft surfaces in the hopes of enabling tissue growth and avoiding poor tissue integration, foreign body immune responses, and high failure rates. Zhou et al. [59] recently functionalized polyethylene terephthalate (PET) grafts with poly (sodium styrene sulfonate) (PNaSS) functional groups and observed fibroblastic cell response. These investigators functionalized PET by first exposing PET fabrics to ozone gas $\left(\mathrm{O}_{3}\right)$, which is unstable and breaks into $\mathrm{O}_{2}$ and $\mathrm{O}_{\bullet}$, the latter of which transfers its free radical to the PET surface making it much more reactive. Under an inert argon atmosphere, the samples were then immersed in a bath of monomer $15 \%(\mathrm{w} / \mathrm{v})$ sodium $p$-(styrene sulfonate) (NaSS) at $65-70^{\circ} \mathrm{C}$ temperature, forming polyNaSS on the PET surface by radical polymerization. The human fibroblast McCoy cell line was seeded onto the functionalized PET surface and observed after 4 days of culture with the live-cell fluorescence label calcein AM. Captured images revealed considerably more cell adherence onto functionalized fibers than non-functionalized fibers. Additionally, dynamic fluid testing indicated that cells adhered to polyNaSS-PET scaffolds compared to PET alone required 12 -fold more shear stress for $50 \%$ of adhered cells to be removed ( $12 \mathrm{dyn} / \mathrm{cm}^{2}$ compared to $1 \mathrm{dyn} / \mathrm{cm}^{2}$ ). The authors attributed these profound results to two factors: the enhanced surface hydrophilicity enabling cell spreading, and the opportunity for fibronectin to bind to the PNaSS, increasing the number of focal adhesion contacts and the potential for organized cytoskeletal formation. It will be particularly interesting when these functionalized grafts are implanted in vivo to test if the foreign body capsulation response still occurs, and if not, how they perform over long term implantation.

\section{B. Decellularized $T / L$ scaffolds}

It has been argued that the best replacement biomaterials for $\mathrm{T} / \mathrm{L}$ are those derived from the $\mathrm{T} / \mathrm{L}$ themselves (when they are available) because the tissues already have similar mechanical properties and because the endogenous integrin binding sites are present and abundant in the native ECM. However, some studies have suggested that allograft tissues can contain residual donor cells even with strict sterilization and cleaning [60], and may cause a significant inflammatory response when implanted in vivo [61]. Furthermore, there are concerns about the extent and efficiency of cellular infiltration particularly to the dense center areas of the graft. Thus, the application of chemical treatments to yield a fully decellularized and more porous scaffold, as opposed to the use of minimally treated allografts [62], is preferred for $\mathrm{T} / \mathrm{L}$ tissue engineering. Whitlock et al. [63] recently addressed this issue with a novel oxidative chemical treatment and a battery of in vitro cytocompatibility and tissue tests. The authors isolated adult chicken flexor digitorum profundus tendons and added $1.5 \%$ peracetic acid to act as an oxidizing agent (using $\mathrm{OH}$ radicals) to create pores in the tissue and remove loose DNA. Simultaneously, the detergent Triton X-100 (polyethylene glycol octylphenyl ether) was also added at $2 \%$ concentration to lyse cell membranes. When compared to non-treated controls, the oxidized scaffolds had no nuclei visibly present (H\&E, DAPI staining) and at minimum $70 \%$ less total DNA, which was considered a promising result. The scaffolds also appeared more porous, and on average had 25\% less elastic modulus and stiffness $(p>0.05)$. Results from a subcutaneous rat in vivo cell infiltration study showed that after 3 weeks, cells with nuclei were present in the outside layers and some inner layers of the scaffold, and that no inflammatory reaction or capsule formation was present. Future studies with human $\mathrm{T} / \mathrm{L}$ allografts utilizing a combination of a lysing agent and oxidiative agent are warranted, and these treatments may prove to be effective in minimizing the foreign body and capsulation responses found with standard allografts.

\section{Effects of growth factors on natural and engineered tendons and ligaments}

One of the most promising strategies to augment natural regeneration is the introduction of growth factors 
with specific activities on target tissues. Of the many growth factors in the body, the following five growth factors have shown promise for $\mathrm{T} / \mathrm{L}$ engineering due to their notable upregulation during $\mathrm{T} / \mathrm{L}$ healing [64]: insulin-like growth factor-I (IGF-I), transforming growth factor- $\beta$ (TGF- $\beta$ ), vascular endothelial growth factor (VEGF), platelet-derived growth factor (PDGF), and basic fibroblastic growth factor (bFGF). Once considered impractical due to their extremely high costs, growth factors have recently been re-evaluated for their possible application for $\mathrm{T} / \mathrm{L}$ tissue engineering [65-68], made possible by biotechnological advancements in the production and purification of recombinant proteins. Of these five growth factors, bFGF has shown particular efficacy and has been known as an effective promoter of $\mathrm{T} / \mathrm{L}$ regeneration since early wound healing studies of canine dental defects [69], and is now beginning to be incorporated into full $\mathrm{T} / \mathrm{L}$ tissue engineering strategies. Sahoo et al. [70] blended bFGF with PLGA and produced electrospun nanofibrous scaffolds capable of releasing $60 \%$ of the growth factor over the course of one week. When these scaffolds were seeded with bonemarrow derived rabbit MSCs and compared against scaffolds without bFGF, the authors found significant increases in cell proliferation, immunostaining of tenascin- $\mathrm{C}$ and collagen types I and III, and gene expression levels of collagen types I and III, fibronectin, and biglycan over 14 days, which are all promising indicators of enhanced T/L differentiation. Impressively, these results were attained with a bFGF concentration of only $11 \mu \mathrm{g} /$ $\mathrm{mL}$ of PLGA (dissolved in hexafluoroisopropanol). Recently, bFGF was also employed in vivo in a rabbit ACL repair model via loading into gelatin hydrogels to form a three-part engineered ligament consisting of a braided fibronectin-coated PLLA core, a collagen membrane wrapping sheet, and the bFGF-loaded gelatin hydrogels [71]. Observation at 8 weeks post-implantation revealed that the addition of bFGF increased both the maximal strength and stiffness of the regenerated ACL by approximately $50 \%$, increased collagen mass in the regenerated tissue by $2.5-4$ fold, and produced histological cross-sections that more closely resembled native ligament. This study demonstrates that local and controlled release of growth factors such as bFGF can be potent accelerators of $\mathrm{T} / \mathrm{L}$ regeneration in vivo.

In addition to bFGF, TGF- $\beta$ has also been implicated as an important growth factor in $\mathrm{T} / \mathrm{L}$ development, and is actively being investigated for applications in T/L tissue engineering. We characterized the spatiotemporal distribution of TGF- $\beta$ in the developing chick tendon during embryonic days 13-16 (Fig. 3; [72]). Histologic results demonstrated rapid tissue organization and development during this time period. Immunohistochemical staining showed TGF- $\beta 2$ and $-\beta 3$, but not
TGF- $\beta 1$, were present within the tendon mid-substance on all days studied. TGF- $\beta 2$ and $-\beta 3$ exhibited similar distribution patterns, but differed in timing and intensity. Taken together, these findings strongly support the postulate that TGF- $\beta 2$ and $-\beta 3$ are involved in tendon development and that these isoforms may have independent roles. This was recently confirmed when TGF- $\beta 2$ and $-\beta 3$ knockout mice were unable to form most tendon and ligaments, and both TGF- $\beta 2$ and $-\beta 3$ were shown to be essential for maintenance of tendon progenitor cells in vivo[73]. In the near future, as production of purified growth factor continues to become more economical, more research on regenerative growth factors will be performed, leading to information that will guide the use of growth factors as integral components of functional $\mathrm{T} / \mathrm{L}$ replacement tissues.

\section{$D$. Effects of cyclic strain on engineered ligaments}

It is well known that locomotion induces tensile strain on T/L tissues, and for more than 100 years [74] it has been theorized and later demonstrated that the density and remodeling of bone is related to its loading state $[75,76]$. Thus it should be no surprise that since nearly the inception of the field, tissue engineers have studied the effect of forces on fibroblasts [77] and later on ACL cells [78]. Subsequent to these preliminary experiments, more elaborate bioreactors with uniaxial or multi-axial applied forces were developed for musculoskeletal tissue engineering. Altman et al. [79] developed a novel cyclic strain bioreactor that simultaneously applied $10 \%$ tensile strain and 25\% torsional strain to MSC-seeded collagen type I gels, designed to mimic the natural $90^{\circ}$ twist on ACL collagen fibers during knee flexion/extension. The stimulation was applied at a rate of $0.0167 \mathrm{~Hz}$ for up to 21 days. Compared to static construct controls, the mechanically stimulated gels had significantly higher cross-sectional cell density and a 2.5 -fold increase in cell alignment. The most striking finding was that the mRNA expression of collagen type I, collagen type III, and tenascin- $\mathrm{C}$ in mechanically stimulated gels were all significantly upregulated compared to static controls and approached native T/L expression, and that bone and cartilage markers were not upregulated. This was the first study to demonstrate that MSCs could begin to be differentiated into $\mathrm{T} / \mathrm{L}$-like lineages using mechanical stimulation alone. The application of cyclic strain in stem cell based bioreactor systems to promote cell proliferation, cell alignment, and T/L-marker expression is now an accepted and widely utilized method in $\mathrm{T} / \mathrm{L}$ tissue engineering [80]. This and other studies have demonstrated enhanced matrix production by MSCs when cyclically loaded under uniaxial tension in longterm cultures, but have not elucidated the mechanisms for these results [81-84]. To investigate potential mechanisms, we conducted short term studies with 


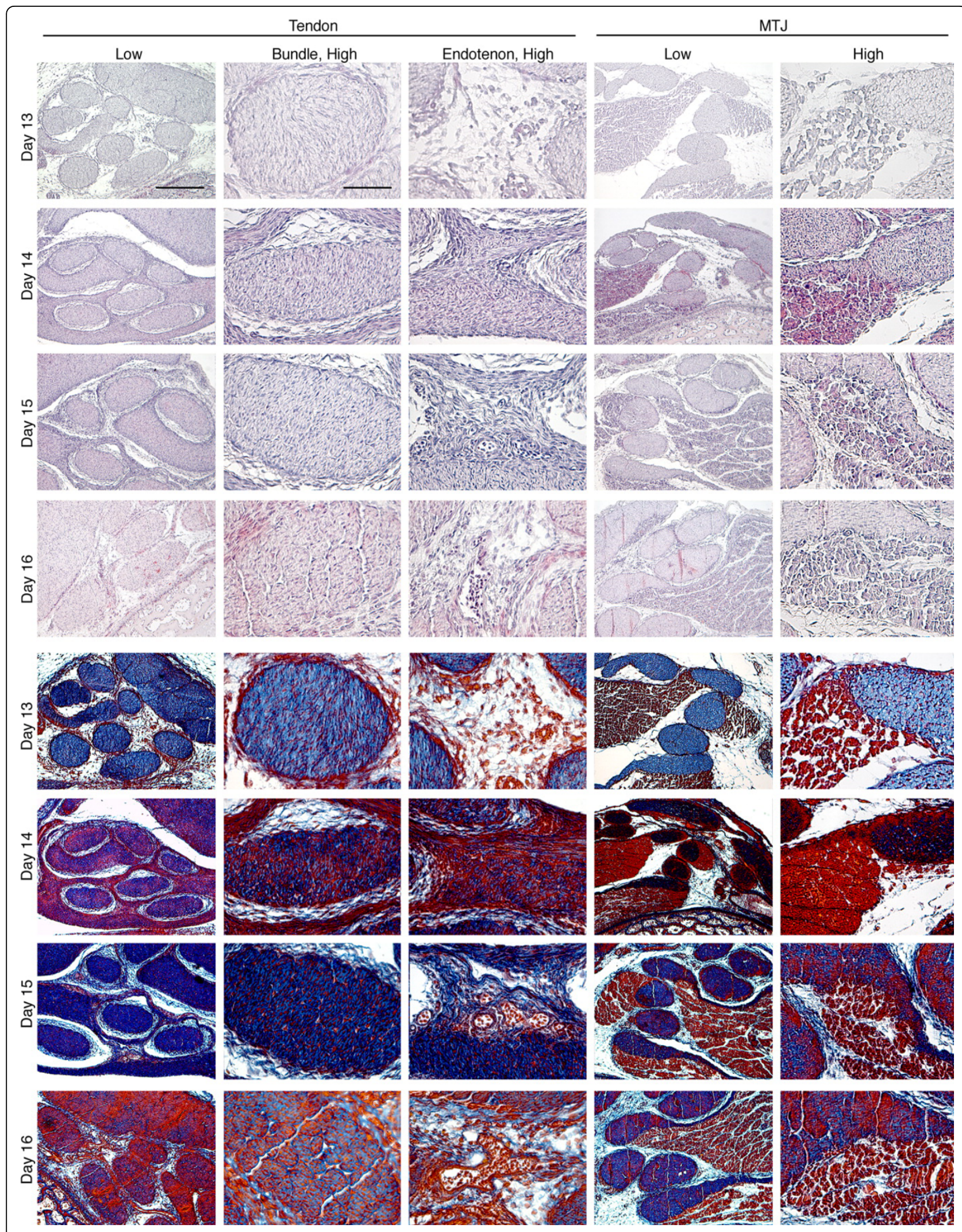

Figure 3 Histology of transverse sections of intermediate tendon of chick embryos at developmental days 13, 14, 15, and 16 [72]. (Top) Hematoxylin-eosin staining; (Bottom) Mallory's trichrome staining. Low magnification, Bar = $200 \mu \mathrm{m}$; high magnification, Bar $=50 \mu \mathrm{m}$. 
human MSCs in a similar model system utilizing collagen type I scaffolds and uniaxial tensile loading, and investigated putative tendon marker expression [85]. Results showed that while static uniaxial tensile loads upregulated scleraxis expression, cyclic loading significantly enhanced collagen matrix production (Fig. 4). Cyclic loading was necessary to sustain mRNA levels of scleraxis, a tendon-specific marker gene, and differentially regulated additional developmental and mature tendon marker molecules, including collagens, Wnts and MMPs. The results of this study supported the premise that dynamic mechanical loading enhances tenogenesis of hMSCs and provided insights into the mechanisms of this process.

Synthetic biomaterials have also been implemented in cyclic strain bioreactors for $\mathrm{T} / \mathrm{L}$ tissue engineering. Moe et al. [86] seeded human dermal fibroblasts on PLGA 10:90 knitted scaffolds and applied 1.8\% tensile strain for 4 hours daily over two weeks at either static, $0.1 \mathrm{~Hz}$ or 1 $\mathrm{Hz}$ strain rates. Using $\mathrm{H} \& \mathrm{E}$ staining the authors found the most substantial cellular alignment with a $0.1 \mathrm{~Hz}$ applied strain rate; however, the scaffold stiffness of mechanically stimulated constructs was significantly less than that of static controls. However, the stiffness was not normalized to cross-sectional area (i.e. elastic modulus), and it is thus difficult to know if cell contraction and/or matrix formation were partially responsible for this result. Raif and Seedhom [87] also seeded cells onto a knitted scaffold, but used non-degradable PET fibers and bovine synovial cells, which appear to have the capacity to be de-differentiated into multipotent cells [88]. The applied strain parameters varied considerably between $0.65-4.5 \%$ strain magnitude at $1 \mathrm{~Hz}$ and was applied for 1-4 hours per day for either 1 or 35 days. The authors found that cell proliferation during short-term application was reduced at 1 hour post-stimulation, but was upregulated 22 hours later. Furthermore, cell proliferation increased as cyclic strain amplitude was increased, suggesting a higher affinity for differentiation or matrix production at lower strain amplitude, or simply less cell proliferation. The long term (35-day) study did not find significant differences except that higher strains tended to result in a higher scaffold cellular density.

In addition to mechanical stimulation, recent studies have investigated the combinatorial effect of mechanical stimulation and cellular alignment. The developing

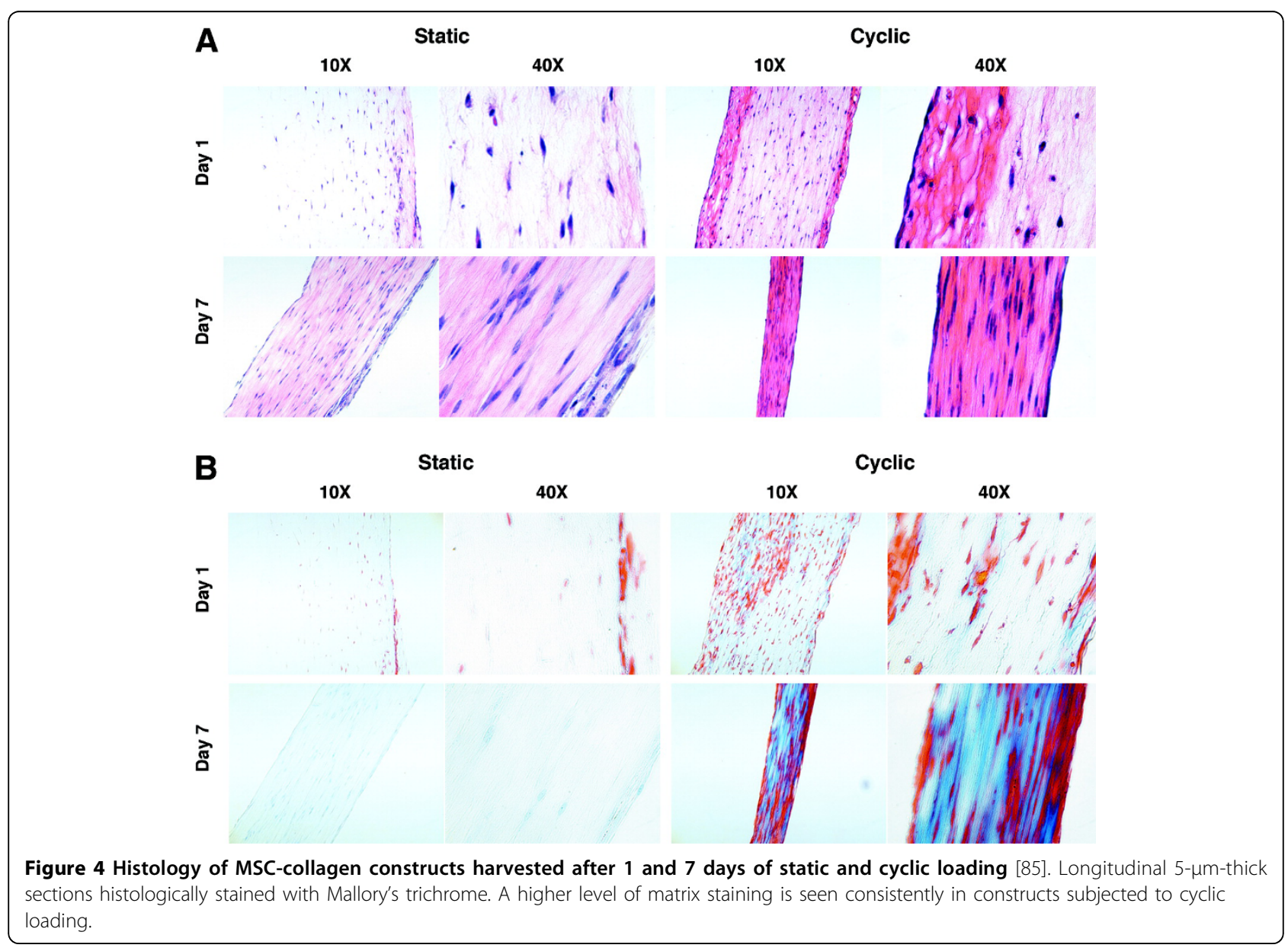


underlying theory of the influence of patterned scaffold structures is known as 'contact guidance', which states that cellular response, especially alignment and proliferation, is dependent on the size and type of the channeling structure. Mechanically stimulating ACL cells seeded on polydimethylsiloxane (PDMS) micropatterned surfaces with an applied $8 \%$ uniaxial strain at $0.5 \mathrm{~Hz}$ for 4 hours a day and 2 days revealed the expression of several novel genes influenced by mechanical stimulation [89]. Specifically, microarray-based real-time PCR analysis showed that expression of the following genes decreased during normal culture but increased after mechanical stimulation: MGP (matrix Gla-protein, 3.8-fold), GADD45A (growth arrest and DNA damageinducible gene, 2.3-fold), UNC5B (unc-5 homolog B, 1.6 -fold), TGFB1 (transforming growth factor- $\beta 1$, 1.4-fold), COL4A1 (collagen type IV $\alpha 1,1.2$-fold), and COL4A2 (collagen type IV $\alpha 2,1.2$-fold). The authors noted that MGP is a small matrix protein that may be involved in cellular differentiation, and that GADD45A may influence cell cycle proteins and play a role in genomic stability. The exact functions of some of these genes in $\mathrm{T} / \mathrm{L}$ biology are not well understood and certainly warrant further investigation, especially with other cell types. In a similar study, Jones et al. [90] seeded rat MCL cells on a microgrooved PDMS substrate and applied $3.5 \%$ strain at $1 \mathrm{~Hz}$ for 2 hours. The authors found considerably more alignment in the groove and stretch direction compared to cells grown on a smooth PDMS surface (Fig. 5), and that intercellular propagation of mechanically induced $\mathrm{Ca}^{2+}$ flux was significantly enhanced with the application of cyclic

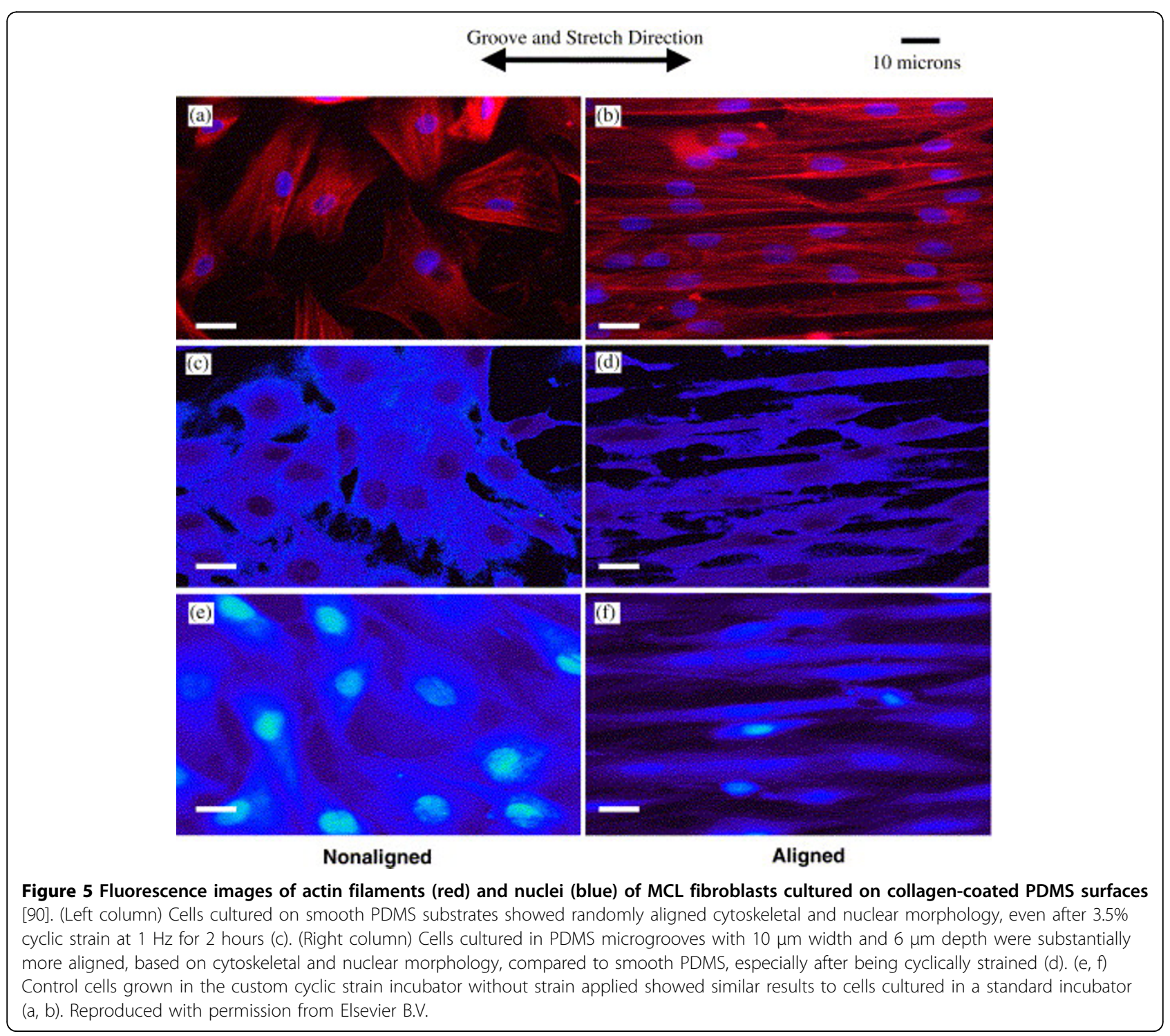


strain $(\mathrm{p}<0.001)$, but not when grooves alone were introduced. Taken together, these findings suggest that uniaxial mechanical stimulation and not only forced cellular alignment is necessary to produce positive benefits for $\mathrm{T} / \mathrm{L}$ tissue engineering.

While mechanical stimulation is a relatively new practice in tissue engineering, it is actively being employed to develop a variety of musculoskeletal engineered tissues, including tendon, ligament, muscle, and bone constructs. In most if not all cases, the addition of cyclic strain has conferred a positive benefit especially with cell proliferation, density, and differentiation of stem cells towards musculoskeletal lineages. However, one important admonition is that the ideal mechanical stimulation regime is far from being described, and specific biological models of mechanical stimulation to tissues are lacking. Thus, given the excellent cost-benefit ratio of applying mechanical stimulation, there is a need for further optimization of applied tissue strains with $\mathrm{T} / \mathrm{L}$ tissue systems, and perhaps in the future applying an optimized mechanical stimulation regime to engineered $\mathrm{T} / \mathrm{L}$ will be commonplace.

\section{Conclusions}

The field of $\mathrm{T} / \mathrm{L}$ tissue engineering is progressing at an increasingly rapid pace; in just 10 years engineered tendons and ligaments have advanced from concept to capable of regenerating large animal ligaments in long term studies. The potential health care implications of engineered $\mathrm{T} / \mathrm{L}$ are extensive and with an aging population will become more important with time.

The design factors for $\mathrm{T} / \mathrm{L}$ engineering have thus far included: native $\mathrm{T} / \mathrm{L}$ anatomy, biomaterial mechanical properties, biomaterial degradation rate, cellular adherence/spreading on biomaterials, and matrix formation. From a biomaterials perspective, it is clear that matching biomaterial properties to the native $\mathrm{T} / \mathrm{L}$ structure and function is a critical consideration. Yet what has also been important for the progression of the field has been the utilization of combinatorial approaches; examples of this include merging braided scaffolds with sponges, merging two materials into a single scaffold, functionalizing a biodegradable surface, or adding mechanical stimulation to aligned cells. In all cases there is not one superior engineered $\mathrm{T} / \mathrm{L}$ design, and thus far the ideal engineered tendon or ligament has yet to be created. Some of the important future milestones of $\mathrm{T} / \mathrm{L}$ tissue engineering include improving the strength and biological integrity of the tendon-muscle and tendon/ligament-bone junctions of implanted engineered $\mathrm{T} / \mathrm{L}$, developing scaffolds and models that match the rate of scaffold degradation with the rate of tissue ingrowth, matching native $\mathrm{T} / \mathrm{L}$ elastic and viscoelastic mechanical properties, and developing $\mathrm{T} / \mathrm{L}$ disease models through tissue engineering. Meeting the demands of these requirements will require concentrated interdisciplinary efforts from biologists, chemists, biomaterials scientists and tissue engineers, which will eventually provide a new and improved option for repair of injured tendons and ligaments to thousands of patients in need of help.

\section{Acknowledgements}

The authors acknowledge research funding support from the National Institutes of Health (CKK) and the Commonwealth of Pennsylvania (RST).

\section{Author details}

'Department of Biomedical Engineering, Tufts University, Medford, MA 02155, USA. ${ }^{2}$ Center for Cellular and Molecular Engineering, Department of Orthopaedic Surgery, University of Pittsburgh School of Medicine, Pittsburgh, PA 15219, USA.

\section{Authors' contributions}

CKK \& JEM wrote the manuscript. RST edited and proofread the manuscript. All authors have read and approved the final manuscript.

\section{Competing interests}

The authors declare that they have no competing interests.

Received: 28 April 2010 Accepted: 20 August 2010

Published: 20 August 2010

\section{References}

1. Lowry OH, Gilligan DR, Katersky EM: The determination of collagen and elastin in tissues, with results obtained in various normal tissues from different species. J Biol Chem 1941, 139:795-804.

2. Nakagawa H, Mikawa $Y$, Watanabe R: Elastin in the human posterior longitudinal ligament and spinal dura: A histologic and biochemical study. Spine 1994, 19:2164-2169.

3. Gineyts E, Cloos PAC, Borel O, Grimaud L, Delmas PD, Garnero P: Racemization and isomerisation of type I collagen C-telopeptides in human bone and soft tissues: assessment of tissue turnover. Biochem $\mathrm{J}$ 2000, 345:481-485.

4. McBride DJ, Trelstad RL, Silver FH: Structural and mechanical assessment of developing chick tendon. Int J Biol Macromol 1988, 10:194-200.

5. Silver FH, Freeman JW, Seehra GP: Collagen self-assembly and the development of tendon mechanical properties. J Biomech 2003, 36:1529-1553.

6. Raspanti M, Congiu T, Guizzardi S: Structural aspects of the extracellular matrix of the tendon: An atomic force and scanning electron microscopy study. Arch Histol Cytol 2002, 65:37-43.

7. Kjær M: Role of extracellular matrix in adaptation of tendon and skeletal muscle to mechanical loading. Physiol Rev 2004, 84:649-698.

8. Robinson PS, Huang TF, Kazam E, lozzo RV, Birk DE, Soslowsky LJ: Influence of decorin and biglycan on mechanical properties of multiple tendons in knockout mice. J Biomech Eng 2005, 127:181-185.

9. Dodds JA, Arnoczky SP: Anatomy of the anterior cruciate ligament: A blueprint for repair and reconstruction. Arthroscopy 1994, 10:132-139.

10. Mikawa Y, Hamagami H, Shikata J, Yamamuro T: Elastin in the human intervertebral disk. Arch Orthop Trauma Surg 1986, 105:343-349.

11. McNeilly CM, Banes AJ, Benjamin M, Ralphs JR: Tendon cells in vivo form a three dimensional network of cell processes linked by gap junctions. J Anat 1996, 189:593-600.

12. Bi Y, Ehirchiou D, Kilts TM, Inkson CA, Embree MC, Sonoyama W, Li L, Leet Al, Seo BM, Zhang L, Shi S, Young MF: Identification of tendon stem/ progenitor cells and the role of the extracellular matrix in their niche. Nature Medicine 2007, 13:1219-1227.

13. Benjamin M, Kaiser E, Milz S: Structure-function relationships in tendons. J Anat 2008, 212:211-228.

14. Schweitzer R, Chyung JH, Murtaugh LC, Brent AE, Rosen V, Olson EN, Lassar A, Tabin CJ: Analysis of the tendon cell fate using Scleraxis, a specific marker for tendons and ligaments. Dev 2001, 128:3855-3866. 
15. Shukunami C, Takimoto A, Oro M, Hiraki Y: Scleraxis positively regulates the expression of tenomodulin, a differentiation marker of tenocytes. Dev Biol 2006, 298:234-247.

16. Chiquet-Ehrismann R, Tucker RP: Connective tissues: signalling by tenascins. Int J Biochem Cell Biol 2004, 36:1085-1089.

17. Woo SLY, Abramowitch SD, Kilger R, Liang R: Biomechanics of knee ligaments: injury, healing, and repair. J Biomech 2006, 39:1-20.

18. Kwan MK, Lin THC, Woo SLY: On the viscoelastic properties of the anteromedial bundle of the anterior cruciate ligament. J Biomech 1993, 26:447-452.

19. Bennett MB, Ker RF, Dimery NJ, Alexander RMN: Mechanical properties of various mammalian tendons. J Zoology A 1986, 209:537-548.

20. Lichtwark GA, Wilson AM: In vivo mechanical properties of the human Achilles tendon during one-legged hopping. J Exp Biol 2005, 208:4715-4725.

21. Maganaris CN, Paul JP: Tensile properties of the in vivo human gastrocnemius tendon. J Biomech 2002, 35:1639-1646.

22. Penn D, Willet TL, Glazebrook M, Snow M, Stanish WD: Is there a significant variation in the material properties of four different allografts implanted for ACL reconstruction. Knee Surg Sports Taumatol ArthrosC 2009, 17:260-265.

23. Lin VS, Lee MC, O'Neal S, McKean J, Sung KP: Ligament tissue engineering using synthetic biodegradable fiber scaffolds. Tissue Eng 1999, 5:443-452.

24. Ouyang HW, Goh JCH, Mo XM, Teoh SH, Lee EH: Characterization of anterior cruciate ligament cells and bone marrow stromal cells on various biodegradable polymeric films. Mat Sci Eng C 2002, 20:63-69.

25. van Wachem PB, Beugeling T, Feijen J, Bantjes A, Detmers JP, van Aken WG: Interaction of cultured human endothelial cells with polymeric surfaces of different wettabilities. Biomaterials 1985, 6:403-408.

26. Lu HH, Cooper JA, Manuel S, Freeman JW, Attawia MA, Ko FK, Laurencin CT: Anterior cruciate ligament regeneration using braided biodegradable scaffolds: in vitro optimization studies. Biomaterials 2005, 26:4805-4816.

27. Cooper JA, Lu HH, Ko FK, Freeman JW, Laurencin CT: Fiber-based tissueengineered scaffold for ligament replacement: design considerations and in vitro evaluation. Biomaterials 2005, 26:1523-1532.

28. Cooper JW, Woods MD, Laurencin CT: Tissue engineering of the anterior cruciate ligament using a braid-twist scaffold design. J Biomech 2007, 40:2029-2036.

29. Chen G, Sato T, Sakane M, Ohgushi H, Ushida T, Tanaka J, Tateishi T: Application of PLGA-collagen hybrid mesh for three-dimensional culture of canine anterior cruciate ligament cells. Mat Sci Eng C 2004, 24:861-866.

30. Pham QP, Sharma U, Mikos AG: Electrospinning of polymeric nanofibers for tissue engineering applications: A review. Tissue Eng 2006, 12:1197-1211.

31. Lee $\mathrm{CH}$, Shin $\mathrm{HJ}$, Cho $\mathrm{HH}_{\text {, Kang } Y M}$, Kim IA, Park KD, Shin JW: Nanofiber alignment and direction of mechanical strain affect the ECM production of human ACL fibroblast. Biomat 2005, 26:1261-1270.

32. Sahoo S, Ouyang H, Goh JCH, Tay TE, Toh SL: Characterization of a novel polymeric scaffold for potential application in tendon/ligament tissue engineering. Tissue Eng 2006, 12:91-99.

33. Sahoo S, Cho-Hong JG, Siew-Lok T: Development of hybrid polymer scaffolds for potential applications in ligament and tendon tissue engineering. Biomed Mat 2007, 2:169-173.

34. Spalazzi JP, Vyner MC, Jacobs MT, Moffat KL, Lu HH: Mechanoactive scaffold induces tendon remodeling and expression of fibrocartilage markers. Clin Orthop Relat Res 2008, 466:1938-1948.

35. Moffat KL, Kwei ASP, Spalazzi JP, Doty SB, Levine WN, Lu HH: Novel nanofiber-based scaffold for rotator cuff repair and augmentation. Tissue Eng Part A 2009, 15:115-126.

36. Fleming BC, Spindler KP, Palmer MP, Magarian EM, Murray MM: Collagenplatelet composites improve the biomechanical properties of healing anterior cruciate ligament grafts in a porcine model. Am J Sports Med 2009, 37:1554-1563.

37. Kinneberg KRC, Nirmalanandhan VS, Juncosa-Melvin N, Powell HM, Boyce ST, Shearn JT, Butler DL: Chondroitin-6-sulfate incorporation and mechanical stimulation increase MSC-collagen sponge construct stiffness. J Orthop Res 2010, 28:1092-1099.

38. Gilbert TW, Stewart-Akers AM, Simmons-Byrd A, Badylak SF: Degradation and remodeling of small intestinal submucosa in canine Achilles tendon repair. J Bone Joint Surg Am 2007, 89:621-630.
39. Derwin K, Androjna C, Spencer E, Safran O, Bauer TW, Hunt T, Caplan A, lannotti J: Porcine small intestine submucosa as a flexor tendon graft. Clin Orthop Relat Res 2004, 423:245-252.

40. Derwin KA, Baker AR, Spragg RK, Leigh DR, lannotti JP: Commercial extracellular matrix scaffolds for rotator cuff tendon repair. Biomechanical, biochemical, and cellular properties. J Bone Joint Surg Am 2006, 88:2665-2672.

41. Roeder BA, Kokini K, Sturgis JE, Robinson JP, Voytik-Harbin SL: Tensile mechanical properties of three-dimensional type I collagen extracellular matrices with varied microstructure. J Biomech Eng 2002, 124:214-222.

42. Kuo CK, Tuan RS: Mechanoactive tenogenic differentiation of human mesenchymal stem cells. Tissue Eng A 2008, 14:1615-1627.

43. Nirmalanandhan VS, Dressler MR, Shearn JT, Juncosa-Melvin N, Rao M, Gooch C, Bradica G, Butler DL: Mechanical stimulation of tissue engineered constructs: Effect of scaffold materials. J Biomech Eng 2007, 129:919-923.

44. Nirmalanandhan VS, Rao M, Shearn JT, Juncosa-Melvin N, Gooch C, Butler DL: Effect of scaffold material, construct length and mechanical stimulation on the in vitro stiffness of the engineered tendon construct. J Biomech 2008, 41:822-828.

45. Yamada H, Nakao H, Takasu Y, Tsubouchi K: Preparation of undegraded native molecular fibroin solution from silkworm cocoons. Mat Sci Eng C 2001, 14:41-46.

46. Kato N, Sato S, Yamanaka A, Yamada H, Fuwa N, Nomura M: Silk protein, sericin, inhibits lipid peroxidation and tyrosinase activity. Biosci Biotechnol Biochem 1998, 62:145-147.

47. Jiang P, Liu H, Wang C, Wu L, Huang J, Guo C: Tensile behavior and morphology of differently degummed silkworm (Bombyx mori) cocoon silk fibres. Mat Lett 2006, 60:919-925.

48. Greenwald D, Shumway S, Albear P, Gottlieb L: Mechanical comparison of 10 suture materials before and after in vivo incubation. J Surg Res 1994, 56:372-377.

49. Minoura N, Tsukada M, Nagura M: Physico-chemical properties of silk fibroin membrane as a biomaterial. Biomat 1990, 11:430-434.

50. Altman GH, Horan RL, Lu HH, Moreau J, Martin I, Richmond JC, Kaplan DL: Silk matrix for tissue engineered anterior cruciate ligaments. Biomat 2002, 23:4131-4141.

51. Liu H, Fan H, Wang Y, Toh SL, Goh JCH: The interaction between a combined knitted silk scaffold and microporous silk sponge with human mesenchymal stem cells for ligament tissue engineering. Biomat 2008, 29:662-674.

52. Woo SLY, Hollis JM, Adams DJ, Lyon RM, Takai S: Tensile properties of human femur-anterior cruciate ligament-tibia complex: the effects of specimen age and orientation. Am J Sports Med 1991, 19:217-225.

53. Chen X, Qi YY, Wang LL, Yin Z, Yin GL, Zou XH, Ouyang HW: Ligament regeneration using a knitted silk scaffold combined with collagen matrix. Biomat 2008, 29:3683-3692.

54. Fan $\mathrm{H}$, Liu H, Wong EJW, Toh SL, Goh JCH: In vivo study of anterior cruciate ligament regeneration using mesenchymal stem cells and silk scaffold. Biomat 2008, 29:3324-3337.

55. Fan H, Liu H, Toh SL, Goh JCH: Anterior cruciate ligament regeneration using mesenchymal stem cells and a silk scaffold in a large animal model. Biomat 2009, 30:4967-4977.

56. Orlando RA, Cheresh DA: Arginine-glycine-aspartic acid binding leading to molecular stabilization between integrin alpha $v$ beta 3 and its ligand. J Biol Chem 1991, 266:19543-19550.

57. Garcia-Fuentes M, Meinel AJ, Hilbe M, Meinel L, Merkle HP: Silk fibroin/ hyaluronan scaffolds for human mesenchymal stem cell culture in tissue engineering. Biomat 2009, 30:5068-5076.

58. Matsumura K, Hyon SH, Nakajima N, Iwata H, Watazu A, Tsutsumi S: Surface modification of poly(ethylene-co-vinyl alcohol): hydroxyapatite immobilization and control of periodontal ligament cells differentiation. Biomat 2004, 25:4817-4824.

59. Zhou J, Ciobanu M, Pavon-Djavid G, Gueguen V, Migonney V: Morphology and adhesion of human fibroblast cells cultured on bioactive polymer grafted ligament prosthesis. Conf Proc IEEE Eng Med Biol Soc 2007, 2007:5115-5118.

60. Zheng MH, Chen J, Kirilak Y, Willers C, Xu J, Wood D: Porcine small intestine submucosa (SIS) is not an acellular collagenous matrix and 
contains porcine DNA: Possible implications in human implantation. J Biomed Mat Res B: Appl Biomat 2005, 73B:61-67.

61. Malcarney HL, Bonar F, Murrell GAC: Early inflammatory reaction after rotator cuff repair with a porcine small intestine submucosal implant. Am J Sports Med 2005, 33:907-911.

62. Musahl V, Abramowitch SD, Gilbert TW, Tsuda E, Wang JHC, Badylak SF, Woo SLY: The use of porcine small intestinal submucosa to enhance the healing of the medial collateral ligament - a functional tissue engineering study in rabbits. J Orth Res 2004, 22:214-220.

63. Whitlock PW, Smith TL, Poehling GG, Shilt JS, Van Dyke M: A naturally derived, cytocompatible, and architecturally optimized scaffold for tendon and ligament regeneration. Biomat 2007, 28:4321-4329.

64. Molloy T, Wang Y, Murrell GAC: The roles of growth factors in tendon and ligament healing. Sports Med 2003, 33:381-394.

65. Chhabra A, Tsou D, Clark RT, Gaschen V, Hunziker EB, Mikic B: GDF-5 deficiency in mice delays Achilles tendon healing. J Orthop Res 2003, 21:826-835.

66. Mikic B, Rossmeier K, Bierwert L: Sexual dimorphism in the effect of GDF6 deficiency on murine tendon. J Orthop Res 2009, 27:1603-1611.

67. Edom-Vovard F, Schuler B, Bonnin MA, Teillet MA, Duprez D: Fgf4 positively regulates scleraxis and tenascin expression in chick limb tendons. Dev Biol 2002, 247:351-366.

68. Thomopoulos S, Das R, Sakiyama-Elbert S, Silva MJ, Charlton N, Gelberman RH: bFGF and PDGF-BB for tendon repair: controlled release and biologic activity by tendon fibroblasts in vitro. Ann Biomed Eng 2010, 38:225-234.

69. Murakami S, Takayama S, Ikezawa K, Shimabukuro Y, Kitamura M, Nozaki T, Terashima A, Asano T, Okada H: Regeneration of periodontal tissues by basic fibroblast growth factor. J Peridontal Res 1999, 34:425-430.

70. Sahoo S, Ang LT, Goh JCH, Toh SL: Bioactive nanofibers for fibroblastic differentiation of mesenchymal precursor cells for ligament/tendon tissue engineering applications. Differentiation 2010, 79:102-110.

71. Kimura Y, Hokugo A, Takamoto T, Tabata Y, Kurosawa H: Regeneration of anterior cruciate ligament by biodegradable scaffold combined with local controlled release of basic fibroblast growth factor and collagen wrapping. Tissue Eng C 2008, 14:47-57.

72. Kuo CK, Petersen BC, Tuan RS: Spatiotemporal protein distribution of TGF$\beta s$, their receptors, and extracellular matrix molecules during embryonic tendon development. Dev Dyn 2008, 237:1477-1489.

73. Pyrce BA, Watson SS, Murchison ND, Staverosky JA, Dünker N, Schweitzer R: Recruitment and maintenance of tendon progenitors by TGF $\beta$ signaling are essential for tendon formation. Development 2009, 136:1351-1361.

74. Wolff J: Das gesetz der transformation der knochen. Dtsch med Wochenschr 1893, 19:1222-1224.

75. Meade JB, Cowin SC, Klawitter JJ, Van Buskirk WC, Skinner HB: Bone remodelling due to contiuously applied loads. Calcif Tissue Int 1984, 36: S25-S30.

76. Carter DR, Orr TE, Fyhrie DP: Relationships between loading history and femoral cancellous bone architecture. J Biomech 1989, 22:231-244.

77. Chiquet-Ehrismann R, Tannheimer M, Koch M, Brunner A, Spring J, Martin D, Baumgartner $S$, Chiquet M: Tenascin-C expression by fibroblasts is elevated in stressed collagen gels. J Cell Biol 1994, 127:2093-2101.

78. Toyoda T, Matsumoto H, Fujikawa K, Saito S, Inoue K: Tensile load and the metabolism of anterior cruciate ligament cells. Clin Orth Related Res 1998, 353:247-255.

79. Altman GH, Horan RL, Martin I, Farhadi J, Stark PR, Volloch V, Richmond JC, Vunjak-Novakovic G, Kaplan DL: Cell differentiation by mechanical stress. FASEB J 2002, 16:267-269

80. Garvin J, Qi J, Maloney M, Banes AJ: Novel system for engineering bioartificial tendons and application of mechanical load. Tissue Eng 2003, 9:967-979.

81. Bhatt KA, Chang El, Warren SM, Lin SE, Bastidas N, Ghali S, Thibboneir A, Capla JM, McCarthy JG, Gurtner GC: Uniaxial mechanical strain: An in vitro correlate to distraction osteogenesis. J Surg Res 2007, 143:329-336.

82. Riboh J, Chong AKS, Pham H, Longaker M, Jacobs C, Chang J: Optimization of flexor tendon tissue engineering with a cyclic strain bioreactor. Biomech Eng 2002, 124:214-222.

83. Zhang L, Kahn CJF, Chen HQ, Tran N, Wang X: Effect of uniaxial stretching on rat bone mesenchymal stem cell: Orientation and expressions of collagen types I and III and tenascin-C. Cell Biol Int 2008, 32:344-352.
84. Chokalingam K, Juncosa-Melvin N, Hunter SA, Gooch C, Frede C, Florert J, Bradica G, Wenstrup R, Butler DL: Tensile stimulation of murine stem cellcollagen sponge constructs increases collagen type I gene expression and linear stiffness. Tissue Eng Part A 2009, 15:2561-2570.

85. Kuo CK, Tuan RS: Mechanoactive tenogenic differentiation of human mesenchymal stem cells. Tissue Eng A 2008, 14:1615-1627.

86. Moe K, Tay TE, Goh JCH, Ouyang HW, Toh SL: Cyclic uniaxial strains on fibroblasts-seeded PLGA scaffolds for tissue engineering of ligaments. Proc SPIE Int Soc Optical Eng 2005, 5852:665-670.

87. Raif EM, Seedhom BB: Effect of cyclic tensile strain on proliferation of synovial cells seeded onto synthetic ligament scaffolds - an in vitro simulation. Bone 2005, 36:433-443.

88. De Bari C, Dell' Accio F, Tylzanowski P, Luyten P: Multipotent mesenchymal stem cells from human synovial membrane. Arthritis Rheumatism 2001, 44:1928-1942.

89. Park SA, Kim IA, Lee YJ, Shin JW, Kim CR, Kim JK, Yang YI, Shin JW: Biological responses of ligament fibroblasts and gene expression profiling on micropatterned silicone substrates subjected to mechanical stimuli. J Biosci Bioeng 2006, 102:402-412.

90. Jones BF, Wall ME, Carroll RL, Washburn S, Banes AJ: Ligament cells stretch-adapted on a microgrooved substrate increase intercellular communication in response to a mechanical stimulus. J Biomech 2005, 38:1653-1664.

doi:10.1186/1758-2555-2-20

Cite this article as: Kuo et al:: Novel strategies in tendon and ligament tissue engineering: Advanced biomaterials and regeneration motifs. Sports Medicine, Arthroscopy, Rehabilitation, Therapy \& Technology 2010 2:20.

\section{Submit your next manuscript to BioMed Central and take full advantage of:}

- Convenient online submission

- Thorough peer review

- No space constraints or color figure charges

- Immediate publication on acceptance

- Inclusion in PubMed, CAS, Scopus and Google Scholar

- Research which is freely available for redistribution

Submit your manuscript at www.biomedcentral com/submit
C Biomed Central 